\title{
Antimicrobial Components of the Neonatal Gut Affected Upon Colonization
}

\author{
YLVA KAI-LARSEN, GUDMUNDUR BERGSSON, GUDMUNDUR H. GUDMUNDSSON, GORDANA PRINTZ, HANS JÖRNVALL, \\ GIOVANNA MARCHINI, AND BIRGITTA AGERBERTH
}

\begin{abstract}
Department of Medical Biochemistry and Biophysics [Y.K.-L., G.B., H.J., B.A.], Karolinska Institutet, SE-171 77 Stockholm, Sweden; Respiratory Research Division, Department of Medicine [G.B.], Royal College of Surgeons in Ireland, Education and Research Center, Beaumont Hospital, Dublin 9, Ireland; Institute of Biology [G.H.G.], University of Iceland, 101 Reykjavik, Iceland; Department of Woman and Child Health [G.P. G.M.], Karolinska University Hospital, SE-171 76 Stockholm, Sweden
\end{abstract}

\begin{abstract}
Antimicrobial peptides (AMP) produced throughout our body are important effectors in the defense barrier of innate immunity. Here, we have analyzed antimicrobial activity and polypeptide composition of meconium versus neonatal feces to address the development of antimicrobial defense of the neonatal gut. Extracts of meconium exhibited antimicrobial activity against Bacillus megaterium, Escherichia coli, and group B streptococci (GBS) but not against the yeast Candida albicans. Extracts of neonatal feces were found to possess low activity against $E$. coli, GBS, and $C$. albicans. However, the anti-B. megaterium activity was higher in the fecal extracts than in meconium. All activities were reduced or abolished when salt was added to the antimicrobial assay. The AMP cathelicidin LL-37, $\alpha$-defensin HNP-1-2, $\alpha$-defensin HD 5, and lysozyme were identified in both meconium and fecal extracts. In addition, HNP-3 and a fragment of azurocidin were found in meconium, whereas the holoprotein azurocidin was detected in feces. In meconium, histones $\mathrm{H} 2 \mathrm{~A}$ and $\mathrm{H} 4$ were isolated and identified by their antimicrobial activity. Notably, LL-37 and lysozyme were found at significantly higher levels in feces than in meconium. Our findings reveal that meconium and feces contain AMP, acting in the defense of the neonatal gut, and may be implicated in the control of the initial colonization. (Pediatr Res 61: 530-536, 2007)
\end{abstract}

$\mathrm{M}^{\mathrm{c}}$ econium is a sterile mucilaginous material that accumulates in the fetal intestine and is expelled soon after birth. It contains secretions of intestinal glands, gut constituents (proteins, bile acids, fatty acids, and steroids), and components of amniotic fluid and vernix caseosa (1). In addition, meconium has been reported to contain proinflammatory substances, including IL- $1 \beta$, IL-6, and IL-8, compounds that are able to induce immune responses such as activation of lymphocytes and chemotaxis of neutrophils $(2,3)$. The first microbes to colonize the intestines of newborn babies are the aerobic bacteria Escherichia coli and Streptococci. Later, the

Received August 22, 2006; accepted December 16, 2006.

Correspondence: Birgitta Agerberth, Ph.D., Department of Medical Biochemistry and Biophysics, Karolinska Institutet, SE-171 77 Stockholm, Sweden; e-mail: birgitta.agerberth@ki.se

This work was supported by The Icelandic Research Fund for Graduate Students, The Swedish Foundation for International Cooperation in Research and Higher Education (STINT), The Swedish Research Council (16X-11217 and 03X-03532), Prof. Nanna Svartz' Foundation, Torsten and Ragnar Söderberg's Foundation, the Icelandic Research Fund, Frimurarbarnhuset in Stockholm, ALF Project Funding, and Crow Princess Lovisa Memory Foundation Y.K.-L., G.B., G.M., and B.A. contributed equally to this study.

DOI: $10.1203 / p d r .0 b 013 e 318045 b e 83$ gut is colonized with anaerobic bacteria, e.g. Bacteroides, Bifidobacteria, and Clostridia. In 1-2 y, the gastrointestinal tract of infants has developed a natural microflora, which resembles the microflora of adults (4).

Despite the fact that newborns have a naive adaptive immune system, infections rarely occur, indicating strong innate defense mechanisms. Several AMP have been characterized in vernix and skin of the newborn, indicating a well-developed innate immune system, which may play a pivotal role at the time of postnatal colonization. AMP are important effectors of innate immunity with the ability to kill a wide range of microbes (5). The defensins and cathelicidins are the two main families of human AMP (6,7). They are expressed at epithelial linings, i.e. the adult human gastrointestinal tract, where they are either constitutively expressed or up-regulated by bacterial factors/ products such as lipopolysaccharides and butyrate (8-11).

In the alimentary tract, polypeptides with bactericidal activities are also present, such as lysozyme, phospholipase $\mathrm{A}_{2}$, different histones, and ribosomal proteins, which have been isolated from adult colonic epithelium and mucosa $(12,13)$. This complex mixture of AMP in colon indicates that the gut is protected against potential human pathogens. A regulatory function of the natural flora has also been suggested for AMP, which may be of significant importance in the neonatal gut (14).

To address whether AMP are produced already in the fetal gut where no microbes are present, meconium was analyzed and found to exhibit activity against both Gram-negative and -positive bacteria. Hence, we show that meconium contains several AMP, indicating the capability of the fetal gastrointestinal tract to produce such factors. However, because bacterial components are known to be important activators of several AMP genes, we hypothesized that this defense system is induced upon colonization. Therefore, we analyzed the antimicrobial activity and polypeptide composition of feces sampled 3-8 d after birth. Our results reveal that the feces samples, compared with meconium samples, exhibited higher

Abbreviations: AMP, antimicrobial peptides; GBS, group B streptococci; HD, human defensin; HNP, human neutrophil peptide; MALDI-MS, matrixassisted laser desorption/ionization mass spectrometry; RP, reversed phase; TFA, trifluoroacetic acid; WCEX, weak cationic exchange chromatography 
Table 1. Neonates included in the study and the presence of $L L-37$, azurocidin, and an azurocidin fragment in the respective samples

\begin{tabular}{|c|c|c|c|c|c|c|c|}
\hline Neonate no. & Gestation age (wk) & Gender & Birth weight & Postnatal age (h or d) & \multicolumn{3}{|c|}{ Polypeptide present $(+)$ or absent $(-)$} \\
\hline \multicolumn{8}{|l|}{ Meconium } \\
\hline 2 & 39 & Female & 3530 & $8 \mathrm{~h}$ & - & ND & ND \\
\hline 3 & 38 & Male & 3150 & $13 \mathrm{~h}$ & - & - & + \\
\hline 4 & 35 & Male & 3200 & $24 \mathrm{~h}$ & ND & ND & ND \\
\hline 7 & 41 & Male & 3900 & $18 \mathrm{~h}$ & + & - & + \\
\hline 8 & 39 & Female & 3490 & $12 \mathrm{~h}$ & + & - & + \\
\hline 9 & 38 & Female & 3140 & $15 \mathrm{~h}$ & - & - & + \\
\hline 10 & 37 & Female & 3010 & $20 \mathrm{~h}$ & + & - & + \\
\hline $13 \neq$ & 41 & Male & 3550 & $22 \mathrm{~h}$ & + & - & + \\
\hline $14 末$ & 39 & Male & 3300 & $8 \mathrm{~h}$ & + & + & + \\
\hline $19 \|$ & 38 & Female & 3390 & $27 \mathrm{~h}$ & - & ND & ND \\
\hline $20 \|$ & 40 & Male & 3480 & $19 \mathrm{~h}$ & - & ND & ND \\
\hline \multicolumn{8}{|l|}{ Feces } \\
\hline 11 & 40 & Female & 3580 & $4 d$ & + & ND & ND \\
\hline 12 & 40 & Male & 4100 & $5 \mathrm{~d}$ & + & + & + \\
\hline $13 末$ & 41 & Male & 3550 & $4 d$ & + & + & - \\
\hline $14 末$ & 39 & Male & 3300 & $3 d$ & + & - & - \\
\hline $15 \ddagger$ & 41 & Female & 3600 & $4 d$ & + & + & - \\
\hline $16 \|$ & 40 & Female & 3620 & $8 \mathrm{~d}$ & + & ND & ND \\
\hline $17 \|$ & 40 & Male & 3520 & $5 \mathrm{~d}$ & + & ND & ND \\
\hline $18 \|$ & 41 & Female & 2915 & $4 d$ & + & ND & ND \\
\hline $19 \|$ & 38 & Female & 3390 & $8 d$ & + & ND & ND \\
\hline
\end{tabular}

$\mathrm{ND}$, not determined.

Extract $\left(100\right.$ or $650 \mu \mathrm{g}$ ) was analyzed except for those originating from neonates marked with ${ }^{*}$ or ${ }^{\|}$, where $5 \mu \mathrm{g}$ or $15 \mu \mathrm{g}$ protein was analyzed, respectively.

antimicrobial activity and contained significantly higher levels of some AMP.

\section{METHODS}

Samples. Meconium and feces samples were collected from diapers of 20 healthy neonates, born at term gestation after uncomplicated pregnancy and delivery (Table 1) and exclusively breast fed. None of the mothers received antibiotics before, during, or after delivery. The parents gave informed consent for their infant to participate in the study. The collected samples were immediately frozen at $-20^{\circ} \mathrm{C}$. Proteins were extracted and enriched from the meconium and feces samples as previously described for vernix samples (15) and quantified with the Bradford method (Bio-Rad, Hercules, CA).

Inhibition zone assay. The antimicrobial assay and the detection of lysozyme were performed according to a modified protocol as previously described (15). As test microbes, Bacillus megaterium (strain BM11), Escherichia coli (strain D21), Candida albicans (strain ATCC 1443), and a clinical isolate of group B streptococci (GBS), verified by a Phadebact Strep B test (Boule Diagnostic AB, Stockholm, Sweden), were used. All assays were performed with and without medium E (16).

Pepsin digestion. Incubation of $150 \mu \mathrm{g}$ extracts was carried out for $5 \mathrm{~h}$ at $37^{\circ} \mathrm{C}$ in $5 \%$ formic acid with $75 \mu \mathrm{g}$ pepsin (Sigma Chemical Co., St. Louis, MO). After lyophilization, the digests were dissolved in $3.5 \mu \mathrm{L} 0.1 \%$ TFA and analyzed with the inhibition zone assay without medium E.

Isolation of AMP. WCEX was performed as previously described (17). Two different gradients of $1 \mathrm{M}$ or $1.5 \mathrm{M}$ ammonium acetate in $0.2 \mathrm{M}$ acetic acid were used, i.e. $0-50 \%$ in $30 \mathrm{~min}$, followed by $50-100 \%$ in $50 \mathrm{~min}$, and $0-20 \%$ in $10 \mathrm{~min}$, followed by $20-100 \%$ in $80 \mathrm{~min}$. Fractions containing antimicrobial activity were further loaded on an Ace $\mathrm{C}_{18}$ column $(5 \mu \mathrm{m}$; $150 \times 2.1 \mathrm{~mm}$; Advanced Chromatography Technologies, Aberdeen, Scotland). The $\mathrm{C}_{18}$ column was equilibrated in $0.1 \%$ TFA and elution was carried out with a linear gradient of acetonitrile containing $0.1 \%$ TFA at a flow rate of $0.2 \mathrm{~mL} / \mathrm{min}$
SDS-Page. Extracts/fractions were analyzed with SDS-PAGE utilizing $10-20 \%$ Tricine gels or NuPAGE gels (Invitrogen, Carlsbad, CA), which were stained with SilverXpress (Invitrogen) or used for Western blot analysis.

Western blot and dot blot analyses. The presence of LL-37, azurocidin, and HNP-1-3 in extracts/fractions was determined with Western blot or dot blot analyses as previously described (15). The following concentrations of the primary antibodies were as follows: MAb specific for LL-37, $0.6 \mu \mathrm{g} / \mathrm{mL}$; polyclonal antibodies directed to azurocidin, $2 \mu \mathrm{g} / \mathrm{mL}$; and MAb for HNP$1-3,0.2 \mu \mathrm{g} / \mathrm{mL}$. The concentrations of the secondary antibodies (Amersham Pharmacia Biotech, Inc., Piscataway, NJ) were anti-mouse $\operatorname{IgG}(1: 5000)$ for the MAb and anti-rabbit $\operatorname{IgG}$ (1:5000) for the polyclonal antibodies. Immunoreactive protein bands were visualized with ECL-plus (Amersham Pharmacia Biotech, Inc.).

Trypsin digestion and peptide mass fingerprinting. Aliquots of HPLC fractions were lyophilized, redissolved in $0.25 \mathrm{M}$ ammonium bicarbonate $(\mathrm{pH}$ 8 ), and treated with $10 \mu \mathrm{g} / \mathrm{mL}$ trypsin for $4 \mathrm{~h}$ at $37^{\circ} \mathrm{C}$. Fragments were analyzed by MALDI-MS and proteins were identified by database searches using the ProteinProspector MS-Fit program (http://prospector.ucsf.edu/) on the mass values of the tryptic fragments (18).

Protein identification. Material in HPLC fractions and tryptic fragments thereof were analyzed by MALDI-MS and/or amino acid sequence analysis as described previously (19).

Statistical methods. Statistical differences between groups were assessed with two-tailed nonparametric test Mann-Whitney test with a 95\% confidence interval. $p$ Values below 0.05 were considered significant.

\section{RESULTS}

Antimicrobial activity in meconium and feces extracts. The lyophilized meconium extracts were dissolved in $0.1 \%$ TFA and contained $0.5-7.2 \%(\mathrm{wt} / \mathrm{wt})$ proteins. These extracts 


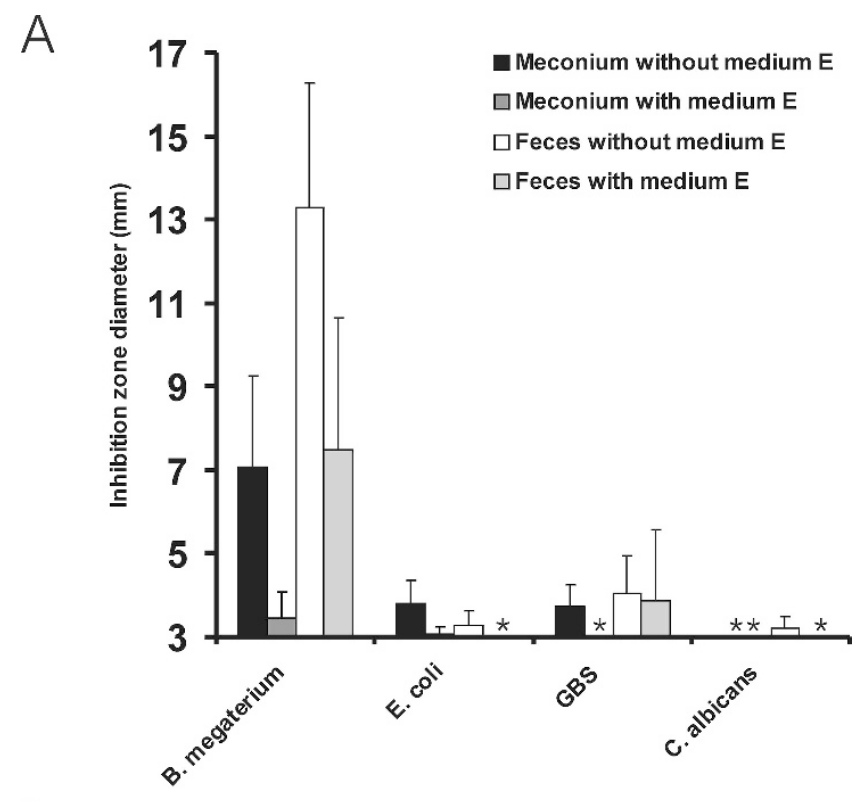

B

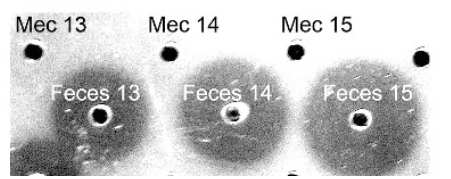

Figure 1. Antimicrobial activities in extracts of meconium and feces. (A) The activities against $B$. megaterium, E. coli, GBS, and $C$. albicans were analyzed with and without medium E. Each column representing meconium is the average of 14 samples. Due to limitations in the amount of material, nine samples were measured in triplicates, two samples in duplicates, and three samples as single measurement. Each bar representing fecal activity is the average of nine samples. Three of these samples were measured in triplicates, and six of the samples in duplicates. The error bars indicate the SEM. *No activity was recorded against the microbe of interest under the given conditions. (B) The lysozyme activity is shown in meconium and fecal samples originating from three neonates (neonates 13-15). The zones were recorded after one night incubation and the assay was repeated twice.

$(150 \mu \mathrm{g})$ were assayed for antimicrobial activity against $B$. megaterium, E. coli, GBS, and C. albicans and exhibited antimicrobial activity against all microbes tested except $C$. albicans (Fig. 1A). When medium $\mathrm{E}$ was included in the assay, the activity against $B$. megaterium was reduced $(p<0.0001)$, whereas the activities against $E$. coli and GBS were abolished (Fig. 1A). Pepsin degradation of the meconium extracts gave a slightly decreased activity against B. megaterium (9\%). However, it did not alter the activity against GBS and it caused an increase of the anti-E. coli $(18 \%)$ activity (data not shown).

Fecal extracts $(150 \mu \mathrm{g})$, containing $4.8-24 \%$ (wt/wt) proteins, exhibited significantly higher activity against $B$. megaterium than meconium both with and without medium $\mathrm{E}$ ( $p=0.0001$ and $p=0.0002$, respectively). However, the activities against $E$. coli, GBS, and $C$. albicans were low (Fig. $1 A)$. As for meconium, medium $E$ reduced most of the activity against B. megaterium $(p=0.0028)$, and depleted the low activity against $E$. coli and $C$. albicans. After pepsin digestion, the activity against $B$. megaterium was dramatically reduced (58\%) (data not shown).
To detect and compare the lysozyme activity, eight meconium and fecal extracts, representing $5 \mu \mathrm{g}$ protein, originating from the same newborn, were analyzed in two assays. After one night of incubation, the fecal samples exhibited significantly higher activity than the corresponding meconium samples $(p=0.0002$ ), with zones ranging from 8.2 to $18.2 \mathrm{~mm}$ in diameters, whereas the zones of the meconium samples ranged from 3.0 to $4.6 \mathrm{~mm}$ (Fig. $1 B$ ).

Isolation and identification of AMP in meconium. Meconium extract $(20 \mathrm{mg})$ was loaded onto a WCEX column. Fraction 7 and fractions 53-62 exhibited activity against $B$. megaterium when analyzed with the inhibition zone assay, where medium E was included. Fraction 56, exhibiting the highest activity, eluted at $0.6 \mathrm{M}$ ammonium acetate (Fig. 2A). Material in this fraction was further purified by reversed phase (RP) chromatography (Fig. 2C) and screened for mass values that correspond to known AMP. The fraction eluting at 23\% acetonitrile contained the $\alpha$-defensins human neutrophil peptides (HNP) of types 1-3 as identified with MALDI-MS (Fig. $2 D$ and Table 2). The HD type 5 was identified in the fraction eluting at $29 \%$ acetonitrile with MALDI-MS and N-terminal sequence analysis for 13 cycles (ATXYXRTGRXAXR) (Fig. $2 E$ and Table 2).

The fraction eluting at $0.54 \mathrm{M}$ ammonium acetate (fraction 50 in Fig. 2A) from the WCEX-HPLC was further separated using RP chromatography (Fig. $2 B$ ). With $\mathrm{N}$-terminal sequence analysis of the material eluting at $37 \%$ acetonitrile, the sequence GRXAXPRQFPFLASI was obtained. This sequence shared significant identity with residues $4-18$ of the antimicrobial polypeptide azurocidin. Further analysis with MALDI-MS gave molecular weights of $4048 \mathrm{Da}$ and $4054 \mathrm{Da}$. The theoretical mass value of $4041 \mathrm{Da}$, corresponding to residues 4-39 of the mature azurocidin protein, is the closest to the observed mass values.

To scale up the purification procedure, $45 \mathrm{mg}$ meconium extract was separated on WCEX-HPLC. The fractions were screened for anti-B. megaterium activity without addition of medium $\mathrm{E}$ in the assay and activity was detected in fractions 5-9, 27, and 53-81. Material eluting at 0.80-0.84 $\mathrm{M}$ ammonium acetate (fractions $60-62$ in Fig. $3 A$ ), was pooled and submitted to RP-HPLC (Fig. $3 B$ ). When material in fractions eluting at $47 \%$ and $51 \%$ acetonitrile, was loaded onto a tricine gel, a single polypeptide band was visualized in each fraction (inset in Fig. $3 B$ ). More accurate molecular weights, $11.3 \mathrm{kDa}$ and $13.9 \mathrm{kDa}$, were obtained with MALDI-MS (Table 2). Attempts to determine the N-terminal sequence of these polypeptides failed, suggesting that they were $\mathrm{N}$-terminally blocked. Hence, they were identified with peptide mass fingerprinting, and found to be histone $\mathrm{H} 4$ and $\mathrm{H} 2 \mathrm{~A}$, which are indeed N-terminally blocked (20). Histone H4 was identified with eight matching fragments in $62 \%$ total sequence coverage, and histone $\mathrm{H} 2 \mathrm{~A}$ with seven matching fragments in $40 \%$ total sequence coverage.

Isolation and identification of fecal AMP. An isolation protocol, identical to that of $20 \mathrm{mg}$ meconium extract, was used for $20 \mathrm{mg}$ feces extract to detect the same polypeptides in the respective material. Anti-B. megaterium activity was detected in fractions $21-25$ and 36-96 from the WCEX- 
A

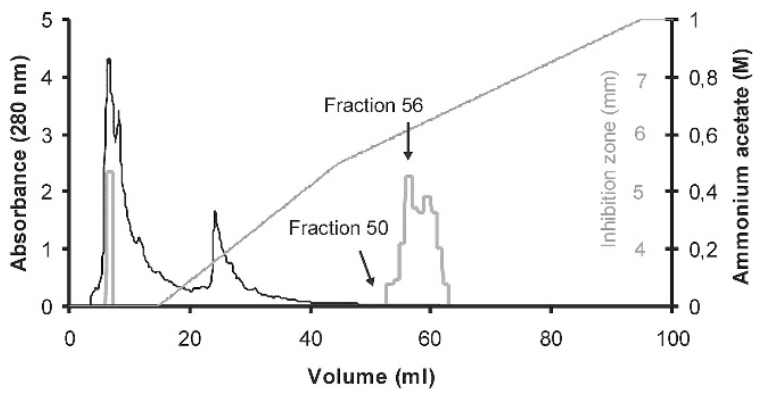

B

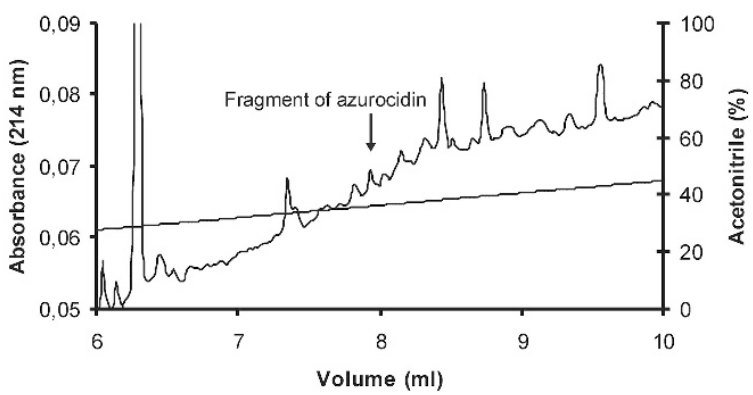

C

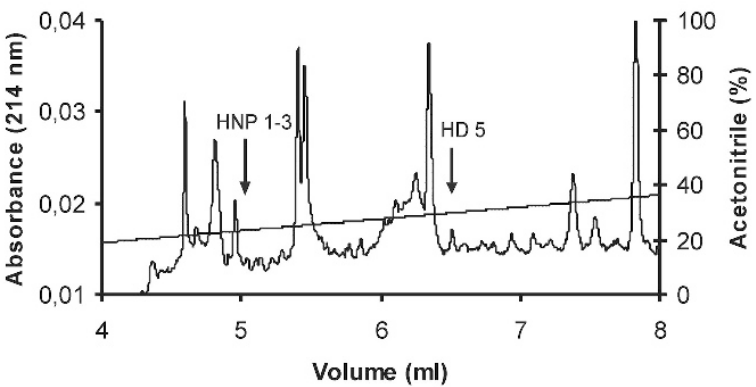

D

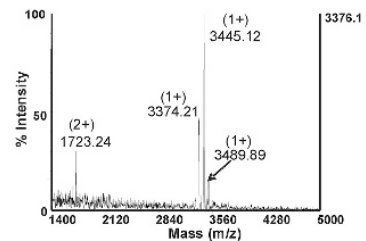

E

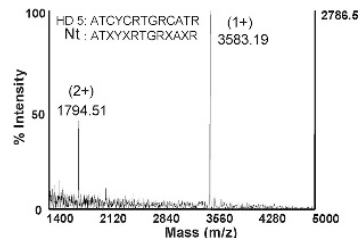

Figure 2. Isolation and identification of AMP from $20 \mathrm{mg}$ meconium extract. (A) The initial step was performed utilizing WCEX-HPLC and the fractions were lyophilized and dissolved in $30 \mu \mathrm{L} 0.1 \%$ TFA before analyzing the antimicrobial activity. The anti- $B$. megaterium activity of the material in the fractions is shown by the gray line. $(B)$ The material in fraction 50 was further loaded onto a RP column and a fragment of azurocidin was identified with N-terminal sequence analysis and MALDI-MS in the fraction eluting at $37 \%$ acetonitrile. ( $C$ and $D$ ) The most active material (fraction 56 in $A$ ) was loaded onto a RP column and at 23\% acetonitrile HNP-1 (3444 Da), HNP-2 (3373 Da), and HNP-3 (3489 Da) were identified with MALDI-MS. (E) In fraction eluting at $29 \%$ acetonitrile (in $C$ ), HD 5 was identified with $\mathrm{N}$-terminal sequence analysis (Nt) and the mass value was determined with MALDI-MS (3582 Da).

HPLC when analyzed without medium E (Fig. 4A). The active fractions $80-84$ eluting at $0.84-0.89 \mathrm{M}$ ammonium acetate (Fig. 4A) were pooled. This material was further separated, utilizing RP-HPLC (Fig. 4B). In the fraction eluting at $29 \%$ acetonitrile HD 5 (Fig. $4 B$ ) was identified with MALDI-MS (Fig. 4C). In addition, HNP-1-2 were isolated in a fraction eluting at $34 \%$ acetonitrile (Fig. $4 B$ ) and identified with both MALDI-MS (Fig. 4D) and dot blot analysis.

Immunodetection of LL-37 in meconium and feces. To address whether the LL-37 level is altered after colonization, $5 \mu \mathrm{g}$ (neonates 13-15) or $15 \mu \mathrm{g}$ (neonates 16-20) protein samples, originating from both meconium and feces of the same neonates, were analyzed. In six of eight fecal samples, LL-37 and/or its proform were present at higher levels than in the corresponding meconium sample (Fig. 5A). Furthermore, additional eight meconium samples and two feces samples from noncorresponding newborns were analyzed for the presence of LL-37 with Western blot analysis (100 $\mu \mathrm{g}$ extract). A faint immunoreactive band of $4.5 \mathrm{kD}$ corresponding to LL-37 was detected in five meconium extracts. Furthermore, LL-37 and its proform $(17 \mathrm{kD})$ were detected in both feces extracts (Table 1).

Immunodetection of azurocidin and an azurocidin fragment in extracts of meconium and feces. As for LL-37, the azurocidin levels in meconium and feces were compared with Western blot analysis. Three extracts ( $5 \mu \mathrm{g}$ protein) of both meconium and feces derived from the same neonates were analyzed. Two of the fecal samples and one meconium samples contained azurocidin (Table 1). Moreover, the presence of azurocidin was analyzed in 7 meconium samples $(650 \mu \mathrm{g}$ extract) and 1 fecal sample (100 $\mu \mathrm{g}$ extracts) from different newborns. In the feces sample, azurocidin $(37 \mathrm{kD})$ was detected. In all meconium extracts a clear immunoreactive band with a mobility corresponding to a molecular weight close to $4 \mathrm{kD}$ was observed, confirming the presence of a fragment of azurocidin (Fig. 5B, Table 1) as isolated and characterized (Fig. 2B).

\section{DISCUSSION}

In this study, we show that meconial and fecal extracts exhibit antimicrobial activity. We have also identified AMP in these extracts, reflecting their presence in the fetal/neonatal gut. In addition, some of these peptides are further induced, most probably in response to postnatal colonization of the gastrointestinal tract.

Meconium extracts were found to be active against $B$. megaterium, E. coli, and GBS. Notably, E. coli and GBS are among the first microbes to colonize the gut where they become a part of the commensal flora. However, if our host defense mechanisms are not able to control the growth of these bacteria, they can cause disease. The newborns are immunologically naive, therefore GBS and E. coli are common pathogens of infants $(4,21)$. The microbicidal properties of meconium suggests that it has a protective role in the neonatal gut and may define the set point of microbial colonization. The antimicrobial defense mechanisms might be crucial for the fetus in its transition from the sterile environment of the uterus to a world rich in bacteria. Fecal extracts were found to be significantly more active against $B$. megaterium than meconium and possess activity against all microbes tested. This indicates that the production of antimicrobial substances is triggered upon contact with microbes present in the gut after birth. 
Table 2. AMP identified in meconium and feces

\begin{tabular}{|c|c|c|c|c|}
\hline $\begin{array}{c}\text { Component } \\
\text { (accession no.) }\end{array}$ & $\begin{array}{l}\text { WCEX-HPLC elution } \\
\text { (M ammonium acetate) }\end{array}$ & $\begin{array}{l}\text { RP HPLC elution } \\
\text { (\% acetonitrile) }\end{array}$ & $\begin{array}{l}\text { Method of } \\
\text { identification }\end{array}$ & $\begin{array}{l}\text { Theoretical mass/ } \\
\text { determined mass }\end{array}$ \\
\hline \multicolumn{5}{|l|}{ Meconium } \\
\hline HNP-1 (P59665) & 0.60 & 23 & MS & $3442 \mathrm{Da} / 3444 \mathrm{Da}$ \\
\hline HNP-2 (P59665) & 0.60 & 23 & MS & $3371 \mathrm{Da} / 3373 \mathrm{Da}$ \\
\hline HNP-3 (P59666) & 0.60 & 23 & MS & $3486 \mathrm{Da} / 3489 \mathrm{Da}$ \\
\hline HD 5 (Q01523) & 0.60 & 29 & MS, NTSA & $3582 \mathrm{Da} / 3582 \mathrm{Da}$ \\
\hline LL-37 (P49913) & NA & NA & WBA & $4493 \mathrm{Da} / 4.5 \mathrm{kDa}$ \\
\hline Histone H2A (Q99878) & $0.80-0.84$ & 51 & PMF & $13.9 \mathrm{kDa} / 13.9 \mathrm{kDa}$ \\
\hline Histone H4 (P62805) & $0.80-0.84$ & 47 & PMF & $11.4 \mathrm{kDa} / 11.3 \mathrm{kDa}$ \\
\hline Lysozyme (P61626) & NA & NA & M. lysodeikticus* & $16.5 \mathrm{kDa} / \mathrm{NA}$ \\
\hline Azurocidin fragment (CAA41601) & 0.54 & 37 & MS, NTSA, WBA & $4041 \mathrm{Da} / 4048,4054 \mathrm{Da}$ \\
\hline \multicolumn{5}{|l|}{ Feces } \\
\hline HNP-1 (P59665) & $0.84-0.89$ & 34 & MS, dot blot analysis & $3442 \mathrm{Da} / 3448 \mathrm{Da}$ \\
\hline HNP-2 (P59665) & $0.84-0.89$ & 34 & MS, dot blot analysis & $3371 \mathrm{Da} / 3376 \mathrm{Da}$ \\
\hline HD 5 (Q01523) & $0.84-0.89$ & 29 & MS & $3582 \mathrm{Da} / 3584 \mathrm{Da}$ \\
\hline LL-37 (P49913) & NA & NA & WBA & $4493 \mathrm{Da} / 4.5 \mathrm{kDa}$ \\
\hline Lysozyme (P61626) & NA & NA & M. lysodeikticus & $16.5 \mathrm{kDa} / \mathrm{NA}$ \\
\hline Azurocidin (CAA41601) & NA & NA & WBA & $37 \mathrm{kDa} / 37 \mathrm{kDa}$ \\
\hline
\end{tabular}

MS, mass spectrometry; NTSA, N-terminal sequence analysis; WBA, Western blot analysis; PMF, peptide mass fingerprinting; NA, not applicable.

${ }^{*}$ See method for lysozyme detection.

The meconial and fecal bactericidal activities were reduced or abolished when salt was added to the inhibition zone assay. This suggests that the majority of the antimicrobial components in both meconium and feces are salt-sensitive. Examples of AMP possessing lower antimicrobial activity at high salt concentrations are the $\alpha$-defensins HNP and HD $5(22,23)$,

\section{A}

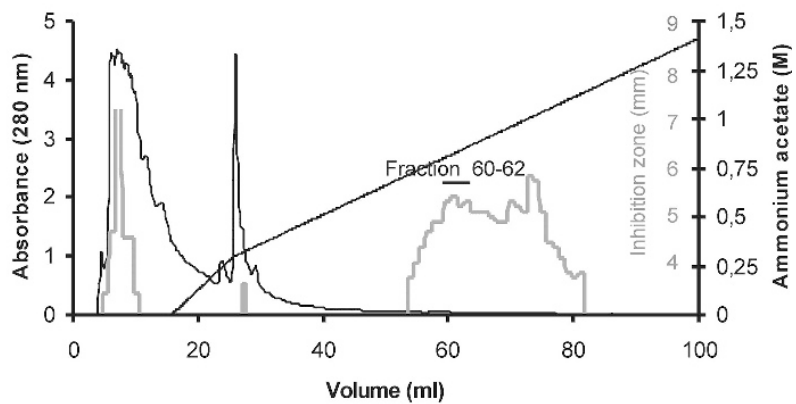

B

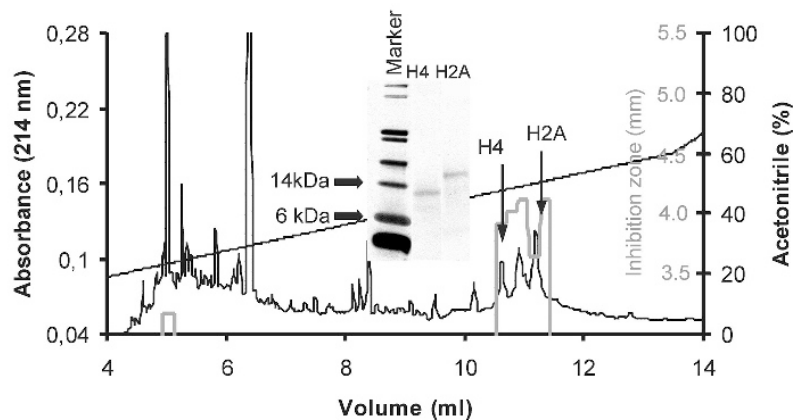

Figure 3. Purification and characterization of AMP from $45 \mathrm{mg}$ meconium extract. (A) The initial fractionation was performed using WCEX-HPLC. After lyophilization, each fraction was dissolved in $65 \mu \mathrm{L} 0.1 \%$ TFA. The material in the fractions was screened against $B$. megaterium and the activity is indicated by the gray line. Fractions 60-62 containing active material was loaded onto a RP column. (B) The active fractions 44 and 48 contained single protein bands, detected with SDS-PAGE (inset). Those proteins were identified as histone $\mathrm{H} 4$ and $\mathrm{H} 2 \mathrm{~A}$ by utilizing peptide mass fingerprinting and MALDI-MS.
A

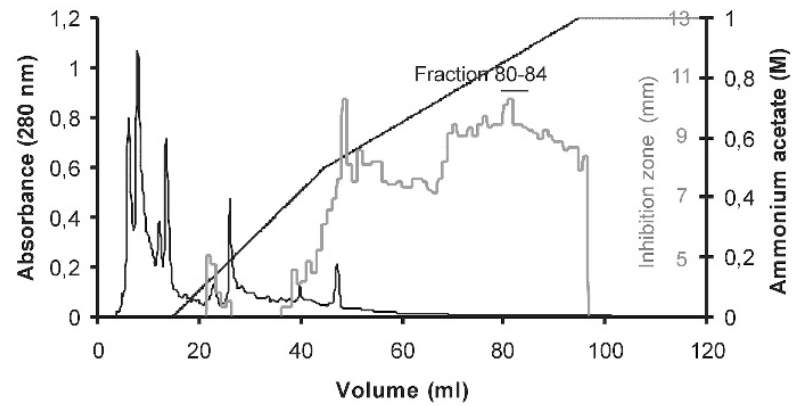

B

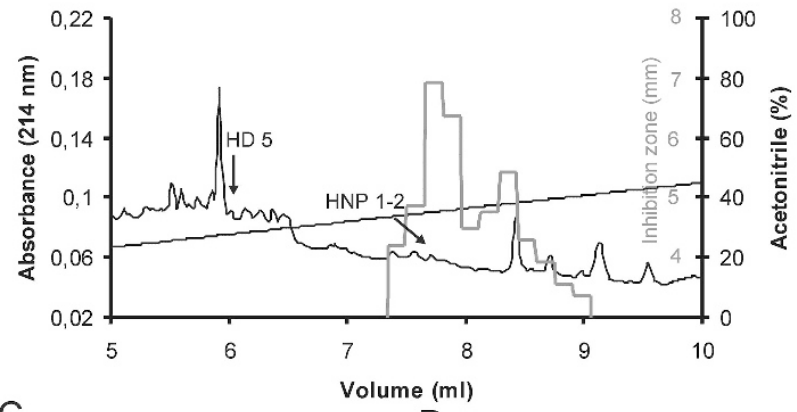

C

D

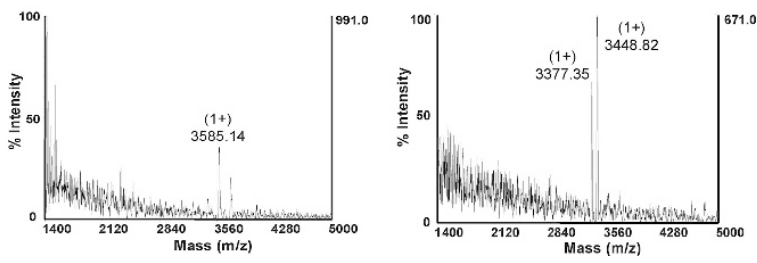

Figure 4. Isolation and identification of AMP in feces extract. $(A)$ The first separation was performed with WCEX-HPLC and after lyophilization each fraction was dissolved in $30 \mu \mathrm{L} 0.1 \%$ TFA. The anti- $B$. megaterium activity was monitored and is indicated by the gray line. $(B)$ The active fraction 80-84 were pooled and loaded onto a RP column. HD 5 eluted at the same percent acetonitrile (29\%) in $B$ as in the chromatography of meconium, and $(C)$ was identified with MALDI-MS. HNP-1-2 eluted at 34\% acetonitrile in $B$ and $(D)$ were identified with MALDI-MS together with dot blot analysis. 

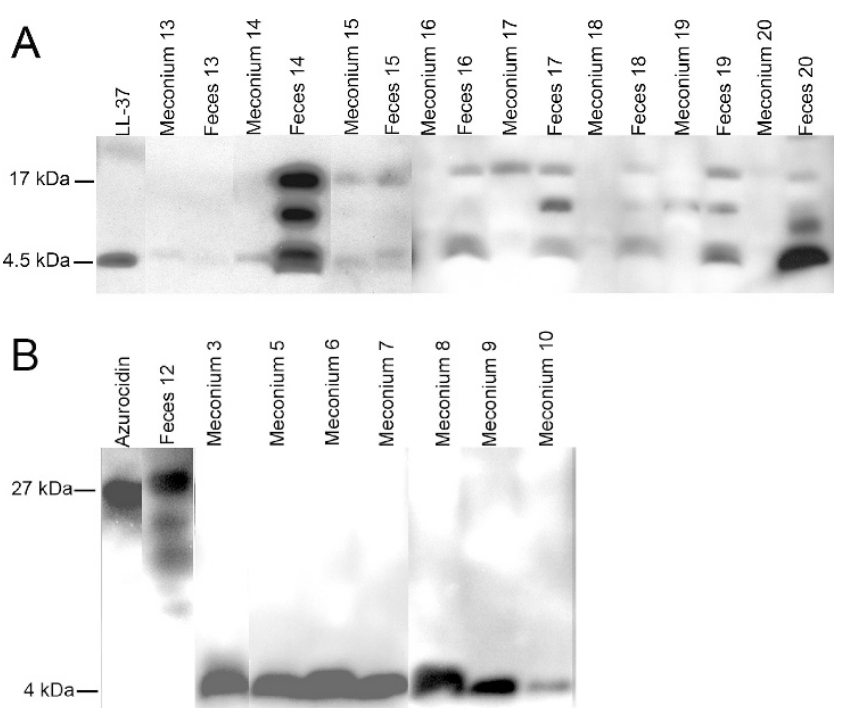

Figure 5. Detection of LL-37 and azurocidin in meconium and neonatal feces extracts. (A) Protein material (5 or $15 \mu \mathrm{g}$ ) was derived from extract of eight neonates and was analyzed with Western blot analysis. Immunoreactive bands corresponding to LL-37 $(4.5 \mathrm{kD})$ and its proform $(17 \mathrm{kD})$ were detected in both meconium and feces samples and their levels varied between the individual neonates. In six of the eight fecal samples (neonates 14 and 16-20), LL-37 was present at higher levels than in the corresponding meconium sample. $(B)$ Extracts of seven meconium samples and one fecal extract were analyzed with Western blot analysis. An immunoreactive band corresponding to azurocidin $(37 \mathrm{kD})$ together with additional fragments of different sizes were found in the fecal sample using the azurocidin antibodies. In all meconium samples, an immunoreactive band corresponding to a 4-kD fragment of azurocidin was detected. As positive controls, (A) $0.5 \mathrm{ng}$ of synthetic LL-37 and (B) $40 \mathrm{ng}$ of recombinant human azurocidin were used. The difference in molecular weight between the recombinant and native azurocidin can be explained by more glycosylation in the native protein.

here identified in both meconium and feces. However, also salt-induced AMPs, such as LL-37, have here been identified in the material analyzed. Salt promotes the alpha-helical conformation of LL-37, which is necessary for its antimicrobial properties (24). Thus, reduced activity of meconium and feces extracts in the presence of salt indicates that the major contributor to the microbicidal activity may be the defensin-like peptides. However, the existence of LL-37 supports that the defense mechanism is active in different conditions.

After pepsin digestion of the fecal extracts, the anti- $B$. megaterium activity was dramatically decreased. In contrast, meconium extracts treated with pepsin did not show any pronounced reduction of the antibacterial activity. This indicates that components other than AMP, such as fatty acids and bile acids, contribute to the microbicidal activities of meconium, or that pepsin digestion may generate antimicrobial fragments as has been shown for histone H2A (25).

HNP, LL-37, and azurocidin have been shown to be expressed in neutrophils $(6,26,27)$. In addition, LL-37 is expressed in various epithelial cells and specific lymphocytes $(28,29)$. Neutrophil defensins and LL-37 are also present in human colon mucosa, vernix, and amniotic fluid $(13,15,19)$, which make it difficult to establish their original source in meconium.

HD 5 and lysozyme, now identified in meconium and feces, are known to be produced by Paneth cells of the small intestine, and are also present in human breast milk (31-34). HD 5 has here been characterized in material derived from the gastrointestinal tract of the fetus. This suggests that it is produced by the intestine of the fetus in the absence of microbes. This result is supported by Mallow et al. (35), showing that HD 5 mRNA is expressed already at 13.5 wk of gestation in the fetal gut. Putsep et al. (36) have demonstrated that the cryptdins (defensin-homologues in mice) are expressed under germ-free conditions, suggesting that microbes would not be required for the production of cryptidins. On the other hand, AMP can influence the colonization of the gut, since the composition of the luminal bacteria in the HD 5 transgenic mouse differs compared with the wild-type mouse (37).

LL-37 and lysozyme were present at significantly higher levels in feces than in meconium (Fig. $1 B$ and Fig. 5A). Lysozyme originating from breast milk is most likely degraded by digestive enzymes in the gastrointestinal tract of the neonate and is most probably not the source of lysozyme in the fecal extracts. Induced expression of AMP in the gut has been shown to be associated with the presence of bacteria and bacterial products $(9,10)$. Thus, our interpretation is that the expression of lysozyme and LL-37 is induced upon bacterial colonization of the neonatal gut. Interestingly, the azurocidin has a different form in meconium, indicating a specific processing step in the fetal gut that is not present after colonization.

The antimicrobial histones (H2A and $\mathrm{H} 4)$ isolated in this study are cationic proteins usually located in the nucleus where their main function is packing of chromatin. However, histones have been known for their antimicrobial properties for decades and have more recently been linked to innate defenses of the colon $(12,13,38,39)$. Other activities have also been reported for histones, such as hormone-like activity and endotoxic-neutralizing activity in human placenta $(40,41)$. Histone proteins are thus present at extranuclear locations and can be released into the gastrointestinal tract by epithelial cells undergoing apoptosis $(39,42)$. The antimicrobial histones here isolated in meconium may be derived from cells undergoing apoptosis during development (43) and/or turnover of epithelial cells in the fetal intestines, compatible with a role of histones in innate defense.

Our data presented here indicates that colonization affects the level of AMP in the neonatal gut. However, to further elucidate how the innate defense mechanism influences the colonization process, mice models could be used, where different microbicidal peptides and microbial strains of the natural flora of the gut would be monitored at different stages of colonization.

In conclusion, our findings suggest that AMP in meconium and feces act as a defense barrier in the neonatal gut and that this defense system is affected upon colonization after birth.

Acknowledgments. The authors thank E. Cederlund, C. Palmberg, and M. Ståhlberg for excellent assistance, M. Chromek and A. Brauner for the GBS strain, and X. Xie, O. Söhnlein, and L. Lindbom for the azurocidin antibodies. 


\section{REFERENCES}

1. Antonowicz I, Shwachman H 1979 Meconium in health and in disease. Adv Pediatr 26:275-310

2. de Beaufort AJ, Bakker AC, van Tol MJ, Poorthuis BJ, Schrama AJ, Berger HM 2003 Meconium is a source of pro-inflammatory substances and can induce cytokine production in cultured A549 epithelial cells. Pediatr Res 54:491-495

3. de Beaufort AJ, Pelikan DM, Elferink JG, Berger HM 1998 Effect of interleukin 8 in meconium on in-vitro neutrophil chemotaxis. Lancet 352:102-105

4. Mackie RI, Sghir A, Gaskins HR 1999 Developmental microbial ecology of the neonatal gastrointestinal tract. Am J Clin Nutr 69:1035S-1045S

5. Zasloff M 2002 Antimicrobial peptides of multicellular organisms. Nature 415:389395

6. Ganz T 2003 Defensins: antimicrobial peptides of innate immunity. Nat Rev Immunol 3:710-720

7. Zanetti M 2004 Cathelicidins, multifunctional peptides of the innate immunity. J Leukoc Biol 75:39-48

8. Bevins C, Ganz T 2004 Antimicrobial peptides of the alimentary tract of mammals. In: Devine DA, Hancock RE (eds) Mammalian host defense peptides. Cambridge University Press, Cambridge, pp 161-188

9. O'Neil DA, Porter EM, Elewaut D, Anderson GM, Eckmann L, Ganz T, Kagnoff MF 1999 Expression and regulation of the human beta-defensins hBD-1 and hBD-2 in intestinal epithelium. J Immunol 163:6718-6724

10. Schauber J, Svanholm C, Termen S, Iffland K, Menzel T, Scheppach W, Melcher R, Agerberth B, Luhrs H, Gudmundsson GH 2003 Expression of the cathelicidin LL-37 is modulated by short chain fatty acids in colonocytes: relevance of signalling pathways. Gut 52:735-741

11. Hase K, Eckmann L, Leopard JD, Varki N, Kagnoff MF 2002 Cell differentiation is a key determinant of cathelicidin LL-37/human cationic antimicrobial protein 18 expression by human colon epithelium. Infect Immun 70:953-963

12. Howell SJ, Wilk D, Yadav SP, Bevins CL 2003 Antimicrobial polypeptides of the human colonic epithelium. Peptides 24:1763-1770

13. Tollin M, Bergman P, Svenberg T, Jörnvall H, Gudmundsson GH, Agerberth B 2003 Antimicrobial peptides in the first line defence of human colon mucosa. Peptides 24:523-530

14. Boman HG 1991 Antibacterial peptides: key components needed in immunity. Cell 65:205-207

15. Yoshio H, Tollin M, Gudmundsson GH, Lagercrantz H, Jörnvall H, Marchini G, Agerberth B 2003 Antimicrobial polypeptides of human vernix caseosa and amniotic fluid: implications for newborn innate defense. Pediatr Res 53:211-216

16. Vogel HJ, Bonner DM 1956 Acetylornithinase of Escherichia coli: partial purification and some properties. J Biol Chem 218:97-106

17. Bergsson G, Agerberth B, Jornvall H, Gudmundsson GH 2005 Isolation and identification of antimicrobial components from the epidermal mucus of Atlantic cod (Gadus morhua). FEBS J 272:4960-4969

18. Altschul SF, Madden TL, Schaffer AA, Zhang J, Zhang Z, Miller W, Lipman DJ 1997 Gapped BLAST and PSI-BLAST: a new generation of protein database search programs. Nucleic Acids Res 25:3389-3402

19. Tollin M, Bergsson G, Kai-Larsen Y, Lengqvist J, Sjovall J, Griffiths W, Skuladottir GV, Haraldsson A, Jornvall H, Gudmundsson GH, Agerberth B 2005 Vernix caseosa as a multi-component defence system based on polypeptides, lipids and their interactions. Cell Mol Life Sci 62:2390-2399

20. Song OK, Wang X, Waterborg JH, Sternglanz R 2003 An N-alpha-acetyltransferase responsible for acetylation of the $\mathrm{N}$-terminal residues of histones $\mathrm{H} 4$ and $\mathrm{H} 2 \mathrm{~A}$. J Biol Chem 278:38109-38112

21. Gladstone IM, Ehrenkranz RA, Edberg SC, Baltimore RS 1990 A ten-year review of neonatal sepsis and comparison with the previous fifty-year experience. Pediatr Infect Dis J 9:819-825
22. Miyasaki KT, Bodeau AL, Ganz T, Selsted ME, Lehrer RI 1990 In vitro sensitivity of oral, gram-negative, facultative bacteria to the bactericidal activity of human neutrophil defensins. Infect Immun 58:3934-3940

23. Porter EM, van Dam E, Valore EV, Ganz T 1997 Broad-spectrum antimicrobial activity of human intestinal defensin 5. Infect Immun 65:2396-2401

24. Johansson J, Gudmundsson GH, Rottenberg ME, Berndt KD, Agerberth B 1998 Conformation-dependent antibacterial activity of the naturally occurring human peptide LL-37. J Biol Chem 273:3718-3724

25. Kim HS, Yoon H, Minn I, Park CB, Lee WT, Zasloff M, Kim SC 2000 Pepsinmediated processing of the cytoplasmic histone $\mathrm{H} 2 \mathrm{~A}$ to strong antimicrobial peptide buforin I. J Immunol 165:3268-3274

26. Shafer WM, Martin LE, Spitznagel JK 1986 Late intraphagosomal hydrogen ion concentration favors the in vitro antimicrobial capacity of a 37-kilodalton cationic granule protein of human neutrophil granulocytes. Infect Immun 53:651-655

27. Gudmundsson GH, Agerberth B, Odeberg J, Bergman T, Olsson B, Salcedo R 1996 The human gene FALL39 and processing of the cathelin precursor to the antibacterial peptide LL-37 in granulocytes. Eur J Biochem 238:325-332

28. Frohm Nilsson M, Sandstedt B, Sorensen O, Weber G, Borregaard N, StahleBackdahl M 1999 The human cationic antimicrobial protein (hCAP18), a peptide antibiotic, is widely expressed in human squamous epithelia and colocalizes with interleukin-6. Infect Immun 67:2561-2566

29. Agerberth B, Charo J, Werr J, Olsson B, Idali F, Lindbom L, Kiessling R, Jörnvall H, Wigzell H, Gudmundsson GH 2000 The human antimicrobial and chemotactic peptides LL-37 and alpha-defensins are expressed by specific lymphocyte and monocyte populations. Blood 96:3086-3093

30. Deleted in proof.

31. Jones DE, Bevins CL 1992 Paneth cells of the human small intestine express an antimicrobial peptide gene. J Biol Chem 267:23216-23225

32. Peeters T, Vantrappen G 1975 The Paneth cell: a source of intestinal lysozyme. Gut $16: 553-558$

33. Armogida SA, Yannaras NM, Melton AL, Srivastava MD 2004 Identification and quantification of innate immune system mediators in human breast milk. Allergy Asthma Proc 25:297-304

34. Montagne P, Cuilliere ML, Mole C, Bene MC, Faure G 2001 Changes in lactoferrin and lysozyme levels in human milk during the first twelve weeks of lactation. Adv Exp Med Biol 501:241-247

35. Mallow EB, Harris A, Salzman N, Russell JP, DeBerardinis RJ, Ruchelli E, Bevins CL 1996 Human enteric defensins. Gene structure and developmental expression. J Biol Chem 271:4038-4045

36. Putsep K, Axelsson LG, Boman A, Midtvedt T, Normark S, Boman HG, Andersson M $2000 \mathrm{Germ}$-free and colonized mice generate the same products from enteric prodefensins. J Biol Chem 275:40478-40482

37. Wehkamp J, Salzman NH, Porter E, Nuding S, Weichenthal M, Petras RE, Shen B, Schaeffeler E, Schwab M, Linzmeier R, Feathers RW, Chu H, Lima H Jr Fellermann K, Ganz T, Stange EF, Bevins CL 2005 Reduced Paneth cell alpha-defensins in ileal Crohn's disease. Proc Natl Acad Sci U S A 102:18129-18134

38. Hirsch JG 1958 Bactericidal action of histone. J Exp Med 108:925-944

39. Rose FR, Bailey K, Keyte JW, Chan WC, Greenwood D, Mahida YR 1998 Potential role of epithelial cell-derived histone $\mathrm{H} 1$ proteins in innate antimicrobial defense in the human gastrointestinal tract. Infect Immun 66:3255-3263

40. Reichhart R, Zeppezauer M, Jörnvall H 1985 Preparations of homeostatic thymus hormone consist predominantly of histones $2 \mathrm{~A}$ and $2 \mathrm{~B}$ and suggest additional histone functions. Proc Natl Acad Sci U S A 82:4871-4875

41. Kim HS, Cho JH, Park HW, Yoon H, Kim MS, Kim SC 2002 Endotoxinneutralizing antimicrobial proteins of the human placenta. J Immunol 168:23562364

42. Zlatanova JS, Srebreva LN, Banchev TB, Tasheva BT, Tsanev RG 1990 Cytoplasmic pool of histone H1 in mammalian cells. J Cell Sci 96:461-468

43. de Santa Barbara P, van den Brink GR, Roberts DJ 2003 Development and differentiation of the intestinal epithelium. Cell Mol Life Sci 60:1322-1332 